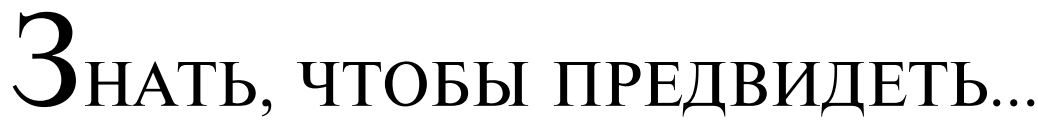

\section{To kNow SO THAT T F ForEser}

УДК 323.1

\section{ЦИВИЛИЗАЦИОННЫЙ ПОАХОА В РОССИИ И ЕГО ИСТОРИЧЕСКАЯ ЭВОАЮЦИЯ}

\author{
В. В. ШИМОВ ${ }^{1)}$ \\ 1) Белорусский государственный университет, пр. Независимости, 4, 220030, г. Минск, Беларусь
}

Рассматриваются особенности эволюции цивилизационного подхода в России, а также исторические этапы становления цивилизационного подхода в русской политической мысли, начиная с дореволюционных времен и заканчивая постсоветским периодом. Анализируются работы Н. Я. Данилевского, Л. Н. Гумилёва, А. Г. Дугина, В. Л. Цымбурского. Делается вывод о том, что цивилизационный подход в России оказался особенно востребован в силу специфического характера отношений России с западным миром и в рамках дискуссии о принадлежности России к европейской цивилизации. В перспективе мир-системного анализа развитие цивилизационной парадигмы в России было обусловлено ее нахождением на полупериферии капиталистической мир-системы, что всегда осложняло взаимоотношения со странами Запада, входящими в мир-системное ядро. Полученные выводы могут быть использованы в рамках исследований процессов становления национальной и социокультурной идентичности на постсоветском пространстве, а также в преподавании дисциплин социогуманитарного блока (политология, история политических учений).

Ключевые слова: цивилизация; цивилизационный подход; варварство; Россия; Европа; Азия.

\section{Образец цитирования:}

Шимов ВВ. Цивилизационный подход в России и его историческая эволюция. Журнал Белорусского государственного университета. Социология. 2021;4:32-38 (на англ.). https://doi.org/10.33581/2521-6821-2021-4-32-38

\section{For citation:}

Shimov VV. Civilisation approach in Russia and its historical evolution. Journal of the Belarusian State University. Sociology. 2021;4:32-38.

https://doi.org/10.33581/2521-6821-2021-4-32-38

\section{Ав тор:}

Всеволод Владимирович Шимов - кандидат политических наук, доцент; доцент кафедры политологии юридического факультета.

\section{Author:}

Vsevolod V. Shimov, PhD (political science), docent; associate professor at the department of political science, faculty of law.

vs.shimoff@gmail.com 


\title{
CIVILISATION APPROACH IN RUSSIA AND ITS HISTORICAL EVOLUTION
}

\author{
V. V. SHIMOV
}

${ }^{a}$ Belarusian State University, 4 Niezaliežnasci Avenue, Minsk 220030, Belarus

The article examines the features of the evolution of the civilisational approach in Russia. The historical stages of the formation of the civilisational approach in Russian political thought, starting from the pre-revolutionary times and ending with the post-Soviet period, are considered. The works of N. Danilevsky, L. Gumilyov, A. Dugin, V. Tsymbursky are analysed. It is concluded that the civilisational approach in Russia was especially in demand due to the specific nature of Russia's relations with the Western world and within the discussion about Russia's belonging to European civilisation. In the perspective of the world-system analysis, the development of the civilisational paradigm in Russia was due to its being on the semi-periphery of the capitalist world-system. It has always complicated relations with the Western countries belonging the world-systemic core. The findings can be used within the study of the processes of formation of national and sociocultural identity in the post-Soviet space, as well as in teaching disciplines of the socio-humanitarian block (political science, history of political doctrines).

Keywords: civilisation; civilisational approach; barbarism; Russia; Europe; Asia.

The civilisational development of the modern world remains one of the main problems of social science. The dispute about the unity and plurality of ways of modern mankind development brings us back to the old question of the unity of human civilisation. The linearuniversalist model of social evolution that emerged in the West in the modern era remained the dominant scientific paradigm for a long time. Its opposition was the civilisational approach, which affirms the plurality of paths of social evolution and the plurality of human civilisations localised in different regions of the planet. The dispute between these two paradigms, as well as attempts to reconcile them $[1 ; 2]$, continue.

Within this article, the evolution of the civilisational approach in Russia will be considered, which can be considered, without exaggeration, the birthplace of this paradigm, and where the civilisational approach still remains an important part of the socio-political discourse.

The demand for a civilisational approach in Russia is due to the specific refraction in Russian culture of the very concept of «civilisation», which arose to designate the West as the most progressive community that stands at the forefront of human development. This idea has received a number of interpretations, either suggesting the pulling up of the remaining communities to the level of an avant-garde civilisation, or denying them such an opportunity. In any case, the idea of a progressive civilisation assumed the ranking of ethnocultural groups according to the level of development, and also formed the prestige of this civilisation, not only in its own eyes, but also in the eyes of so-called backward groups. That is why even the various so-called national liberation movements of the $20^{\text {th }}$ century, which criticised Western «imperialism» and colonial practices, nevertheless existed in the logic of catch-up development and were focused on copying the social institutions and cultural paradigms of the West.

Ranking societies as «advanced» and «backward» inevitably presupposed defining the boundaries between «civilisation» and «barbarism»: which groups should be considered as «civilised» and which - as «backward»? Within the colonial empires (and especially after their collapse), this border between the European metropolises and colonies was clearly marked by geographical distances and barriers, ethnocultural, linguistic and anthropological («racial») differences. In addition to Europe, the concept of «civilisation» («West») also included zones of predominantly Anglo-Saxon colonisation in North America, Australia and New Zealand, where the living standards of «civilised societies» were reproduced, and in the case of the United States, it was promoted to leading roles within the Western world.

However, the definition of the border of «civilisation» in the Eastern Europe met with serious difficulties. Actually, the definition of the «borders of Europe», even in a purely geographical sense, is very problematic, since the very notions of «Europe» and «Asia» as separate entities emerged rather due to a curiosity. This was the name of the parts of the world, located respectively to the west and east of the Aegean Sea, by the ancient Greeks, who believed that along their entire length these two land masses were separated by water. Subsequently, when it became clear that to the north of the Sea of Azov there were no natural boundaries, the division into Europe and Asia acquired a conditional character. By the Modern Times the concept of «Europe» increasingly acquired not a geographical, but a socio-cultural meaning, denoting a community of «Civilised peoples». The concept of Asia underwent a similar metamorphosis, which, on the contrary, became a designation for the «barbarian peoples» living to the east of Europe. But to determine where this border lies between «civilisation» and «barbarism», West and East, Europe and Asia, turned out to be a task as intractable as drawing a purely geographical border between these conventional parts of the world.

The absence of a clear geographical border is aggravated by the absence of the same socio-cultural border 
between «Europe» and «Asia», between which emerges a vast space, which population, both anthropologically and culturally, is close to the «civilised world» of western Europe, but in social terms it bears an imprint of backwardness and «barbarism». The process of understanding by the Western «civilised world» of this peculiar region is described in the famous book by Larry Wolf «Inventing Eastern Europe» [3].

Within the world-systems approach, the backwardness of «Eastern Europe» is explained by the fact that this region found itself in the zone of peripheral development of the capitalist world-system, having occupied a position subordinate to the interests of the «core» countries. In particular, this is why many archaic social practices (landlordism, «second edition of serfdom») were conserved here, which, with their visible archaism, made it possible to effectively extract the resources necessary for the «center» from here. The dependent position in the world-system turned into a prolonged, virtually colonial dependence of the region - a kind of land colonial empire that controlled a large part of «Eastern Europe» was Austria, where there was an indicative saying that Asia begins outside the eastern gates of Vienna.

On the other hand, it is Eastern Europe that has always been considered as the first candidate for pulling up to the level of the «civilised world» and full-fledged entry into it. This region became one of the pioneers of decolonisation and the building of new nation-states, and the entry of Eastern European countries into the EU became a symbol of their «return to civilisation».

Russia in Modern Times found itself in a position even more ambiguous than the rest of Eastern Europe. On the one hand, Russia is perceived as the most eastern, and hence the most «barbaric» part of «Europe», the very «Europeanness» of which turns out to be the most problematic. In the Middle Ages, the border of Europe was usually drawn along the Don or the Dnieper, and most of «Muscovy» was beyond its borders. Therefore, it is no coincidence that under Peter the Great and his successors, efforts were made to consolidate a new understanding of the geographical borders of Europe along the Ural Mountains, which were then perceived as the eastern border of «proper» Russia. On the other hand, New Times Russia is the largest, most populated and politically strong (and in some periods the only independent) country of «Eastern Europe», which could not be content with the role of «just» the periphery of the West. Again, from the point of view of the world-systems analysis, countries like Russia are defined as «semi-peripheral», i. e. occupying an intermediate position between the developed countries of the «center» and «periphery» of the world-system, combining the features of «progressive» development and «backwardness». With regard to Russia, this phenomenon was considered within B. Kagarlitsky's research «Peripheral Empire» [4]. According to Kagarlitsky, in Russia in Modern Times a generally peripheral, dependent model of the economy has developed, focused on serving the interests of the countries of the «center» (first of all, the supply of raw materials - from grain and hemp to oil and gas in different eras). However, while the classical incorporation into the periphery of the world-system was carried out through colonial conquests and political subordination of the «embedded» territories, then in Russia the peripheral economic model was combined with the formation of a strong imperial-type statehood, which allowed it to claim equal status with the powers of the «center». The specificity of the «Russian model» (both pre-Soviet and post-Soviet periods) is that «native» state was engaged in «colonisation» in the interests of the «center». Despite the dependent character of the economy, permanent technological backwardness and the preservation of the features of the social archaic, at the same time it had the potential for territorial expansion, colonial conquests and other forms of building its own sphere of influence, competing with the powers of the «center».

Thus, Russia in Modern Times was a society culturally close to Europe and connected with it by close political and economic ties. At the same time, it did not fit in many parameters into the concept of «European civilisation». This duality predetermined the deep inner contradiction of Russian culture and political consciousness.

On the one hand, the experience of Russia's «backwardness» from the West resulted in a kind of inferiority complex widespread among the Russian intellectual elite. Under the influence of this complex, a whole discourse has developed, which can be collectively designated as Westernism (Zapadnichestvo). For the first time «Westerners» (Zapadniki) emerged in the first half of the $19^{\text {th }}$ century within a discussion with the «Slavophiles», and since then the concept of «Westernism» has been assigned to a fairly stable set of mythologems describing Russia's attitude to the Western world. Within this approach, the idea of Russia as a «backward» European country with «deviating» development is being formed. The reasons for this lag are seen in the historical peculiarities associated with the long isolation from the «civilised» world and the barbaric «Asian» influences to which Russia has been subjected. One of the main reasons for Russia's lagging behind in the Westernising myth is seen as the «Mongol yoke», which has led to an economic and cultural lagging behind, as well as the ingraining of political traditions of despotism and the underdevelopment of democratic institutions.

In some versions of Westernism, other features of Russian culture that distinguish it from Western European culture can be named as the reasons for «backwardness». In particular, after Max Weber's work «Protestant Ethics and the Spirit of Capitalism» appeared, Orthodoxy was often blamed for Russia's lagging behind, which, in contrast to Weber's Protestantism, hindered the development of the entrepreneurial spirit and market economy to which the Western world owes its rise. 
In Westernian logic, the desired development of Russia is seen as catching up, aimed at diligently copying Western socio-political forms and institutions, the elimination of «Asiaticism», which presupposes close integration with the Western world. In extreme forms, this idea presupposes a partial renunciation by Russia of its sovereignty in favour of Western structures, which should take on the functions of «civilising» Russia.

At the same time, the geopolitical and demographic weight of Russia, combined with the growth of the power and capabilities of the Russian state, formed a demand for ideas of greatness and global significance, which naturally came into conflict with the Westernising discourse of Russia as a backward barbarian periphery of Europe. The semi-peripheral status of Russia in the world-system constantly generated a contradiction between the dependent character of the economy and the desire to play the role of an independent and fullfledged «center». We can say that Westernism became an ideological expression of a peripheral, dependent trend in the development of Russia. Therefore, the opposite, conditionally «patriotic» tendency turned out to be directed not only against Westernism, but also against the West as such, which, being the «center» in the world-system, was interested in preserving the semi-peripheral position of Russia.

It is within this «patriotic» discourse that the Russian version of the civilisational approach is being formed. The idea of Russia as a specific civilisation helped to remove the complex of «backwardness» to the West, and cultural features that did not fit into the «European» canon turned into markers of civilisational differences. At the same time, postulating the civilisational independence of Russia, the Russian civilisational approach has always remained within the European and Westernised context. The ideas about the civilisational peculiarity of Russia developed in polemics with Westernism, and the peculiarities of Russian civilisation were realised in constant comparison and opposition with the West. This paradox is easily explained by the specific «under-integration» of Russia into the Western world, which was discussed above. Culturally close to the West and economically connected with it, but at the same time unable to find an acceptable place for itself within it, Russia proclaimed itself a peculiar civilisation, opposing to the West as a civilisational model.

Russian civilisational approach in the $19^{\text {th }}$ and $21^{\text {st }}$ centuries underwent a significant evolution, reflecting the geopolitical and cultural metamorphoses that Russia was experiencing. In pre-revolutionary Russia, the civilisational approach was closely intertwined with PanSlavism. This was the time when the predominantly Slavic peoples of the Eastern European periphery were actively seeking political self-determination. Russia, being the largest country with a predominantly Slavic population, tried to use these movements to expand its own sphere of influence. It is in the Pan-Slavic context
N. Danilevsky's theory of cultural and historical types emerged [5], which can be considered the first integral civilisational theory. Cultural and historical types are autonomously developing territorially localised ethnic communities, each of which has its own special and unique historical path. The Slavs, according to N. Danilevsky, represent a separate cultural and historical type, different from the Romano-Germanic, i. e. European. Imitation of Europe («Europeanism»), excessive political rapprochement with it is destructive for the Slavs, and the relationship of the two cultural-historical types is defined as sharply competitive and often hostile. Russia is defined by N. Danilevsky as the core of the Slavic cultural and historical type, around which all other Slavic peoples will have to rally.

The Russian civilisational approach has also always been characterised by an appeal to Orthodoxy as a religious tradition that determines the civilisational originality of Russia. According to N. Danilevsky, Orthodoxy is not just a Russian, but a Slavic religion. The conversion of Western Slavs to Catholicism is perceived by N. Danilevsky as a result of the destructive influence of Western civilisation, and their «return» to Orthodoxy is seen as one of the key tasks of Russia's civilisational mission.

The crisis of Pan-Slavic ideas became noticeable even before the Revolution 1917, when even some Orthodox conservative thinkers (for example, K. Leont'ev [6]) began to express doubts about the civilisational community of European Slavs with Russia. In addition, the liberating pathos of Pan-Slavism turned not only against the non-Slavic «oppressors», but also against Russia itself, primarily in the «Polish question». The struggle of the Poles against Russia also «awakened» the Ukrainian and Belarusian movements, which challenged not only the ideas of Slavic unity under the auspices of Russia, but also undermined the political unity of the state-forming entity - the Russian people, which before the Revolution 1917 meant the entire community of the Eastern Slavs.

Nevertheless, Pan-Slavist ideas remained popular and continued to influence Russian foreign policy until the First World War and the Revolution 1917, which marked the final crash of Pan-Slavism. After that, the Slavic world was fragmented into many conflicting states, and in Russia the Bolsheviks came to power. New Communist power was far from both pan-Slavic issues and the problem of local civilisations as such.

Therefore, the further development of the civilisational approach was associated with the Russian emigration, in which the concept of Eurasianism was born. Eurasianism was the result of disillusionment with PanSlavism, as the Eurasians themselves wrote about, criticising Pan-Slavist ideas and opposing them with their own concept of Russia - Eurasia. The image of Russia as a civilisation among the Eurasians is «compressed» to the borders of the Russian Empire and the USSR, which 
are described as a natural «development place» of a specific civilisation, which is based on the Russian-Turkic synthesis [7]. The Eurasians turned over the traditional ideas of Russian historiography, presenting the era of the «Mongol-Tatar yoke» as a period of productive synthesis of two Eurasian elements - forest and steppe, Slavs and Turks. In their opinion, it was in this synthesis that the foundations of the Eurasian civilisation were forged. It should be noted that the «Mongol-Tatar yoke» is one of the main negative Westernising myths about Russia, it is with it that Westerners associate its fatal lag and separation from Europe, so this case again clearly shows how close is the connection of the discourse about the civilisational peculiarity of Russia with Westernism and Eurocentrism. Proclaiming an authoritarian ideocratic state as their ideal [8], the Eurasians, again, oppose Russia to the bourgeois-democratic West.

Classical Eurasianism, which emerged at the turn of the 1920s and 1930s, died out rather quickly, but it was revived again, already in the USSR, at the end of the Soviet era, and was associated with the name of L. Gumilyov and his concept of ethnogenesis [9]. L. Gumilyov viewed ethnic groups as natural biological populations, and ethnicity as an innate and unchangeable characteristic of each person. Ethnic groups L. Gumilyov divided into complementary (compatible) and non-complementary (incompatible). Complementary ethnic groups form super-ethnic groups - in fact, analogs of local civilisations. The history of humanity by L. Gumilyov appears as the history of the birth, rise and decline of separate superethnoses. Since L. Gumilyov treats ethnoses and superethnoses in biologising categories, likening them to living organisms, the life cycles of superethnoses are rigid and invariant, with a duration of 1000-1200 years.

L. Gumilyov understands the Russian super-ethnos in the Eurasian spirit as a combination of Slavic and Turkic elements complementary to each other, while Russia is considered as the successor and heir of the empire of Genghis Khan, part of which was the Golden Horde, which conquered northeastern Russia. A rigid authoritarian state is viewed as a Eurasian specificity and «Horde heritage» and is opposed to Western models of a liberal-democratic system. In the opinion of the Eurasians, only such a political structure is capable of tying Eurasia together and meets the interests of the development of all Eurasian peoples.

L. Gumilyov's concept had a certain public resonance at the turn of the 1980s and 1990s, when the USSR was going through an ideological crisis and society was looking for new foundations of its identity. Concepts such as «superethnos» and «passionarity» have come into common use and today continue to be actively used regardless of the original source. At the same time, the obvious scientific inconsistency of the biologising concept of ethnic groups and superethnoses limited the possibilities for the development of Eurasianism on the basis of L. Gumilyov's theory.
Another variation of the Eurasian discourse was the neo-Eurasianism of A. Dugin [10]. This is already a post-Soviet concept aimed at rethinking the place and role of Russia in the world after the collapse of the Communist project. A. Dugin tried to combine Eurasianism with the classical concepts of Western geopolitics based on the confrontation between maritime and continental powers. He understands Russia as a «heartland», «an axis of history» around which the continental forces of Eurasia must rally in their opposition to the «Atlanticists» - the sea powers of the West. A. Dugin breaks with the classical understanding of Eurasia as a «development place» that roughly coincides with the borders of the former USSR. For him, Eurasia is the entire continent, for which Russia plays the role of a pivot, a supporting structure. At the same time, among the «continental» forces, A. Dugin sees the countries of continental Europe, in particular Germany, opposing them to the «Atlantic» powers - Great Britain and the United States.

Eurasian ideas have had a certain impact on the integration processes in the post-Soviet space, in particular, the emergence of the Eurasian Economic Union. In promoting Eurasian ideas, including the L. Gumilyov interpretation, with their emphasis on the significance of the Turkic element, Kazakhstan played an important role, apparently hoping to take the place of an alternative to Russia geopolitical center of the former USSR. The term «Eurasia» or «post-Soviet Eurasia» has also become widespread in Western analytics. However, so far, one can hardly speak of anything more than borrowing the very concept of «Eurasia» to designate a certain geopolitical space, since the Eurasian Economic Union is positioned as a purely economic entity and does not have a distinct ideological dimension.

Perhaps the last iteration of the civilisational approach in Russian political thought to date can be considered the concept of V. Tsymbursky. As Eurasianism at one time arose as a result of disillusionment with Pan-Slavism and in polemics with it, so the doctrine of V. Tsymbursky repels and opposes itself to the previous versions of the civilisational approach.

V. Tsymbursky's concept emerged in the early 1990s, hot on the heels of the collapse of the USSR, and its main task is to «reconcile» Russian society with the new borders in which Russia finds itself. Contrary to the widespread belief that these new boundaries are unfair, V. Tsymbursky argues that it is they that correspond to the natural geopolitical boundaries of the Russian civilisational platform. According to V. Tsymbursky, Russia is not Slavic or Eurasian, but Russian civilisation, i. e. civilisation created by the Russian ethnic groups and determined by the boundaries of their residence. Russia is a geopolitical «island», washed by oceans from the north and east, and surrounded by «strait territories» or limitrophes from the west and south.

The concept of intercivilisational limitrophes plays one of the key roles in V. Tsymbursky's concept. According to his interpretation, the «cores» of civilisations are sur- 
rounded by buffer, intermediate territories, the population and culture of which experience the intermittent influences of neighbouring civilisations. As a result, the limitrophes turn out to be «under-integrated» into any civilisation and oscillate between neighbouring civilisational «cores», either joining or exfoliating from them.

The collapse of the USSR and the socialist camp, according to V. Tsymbursky, just meant the exfoliation of the territories-limitrophes from the civilisational core of Russia. The author assesses this positively, since he believes that the retention of the limitrophes by Russia is counterproductive and sucks resources from the main civilisational core.

As for other Russian authors, for V. Tsymbursky, an important topic is the relationship between Russia and Europe. He considers Russia to be an independent, but «contextually linked» civilisation. This means that Russia, being a young and immature civilisation, found itself caught in the gravitational field of a stronger and more developed civilisation - the West. This explains the numerous borrowings and imitations (pseudomorphosis) characteristic of Russian culture. From here comes Russian Westernism and the desire to become a part of the Western world, which V. Tsymbursky defines as «the complex of the abduction of Europe». In geopolitical terms, this determined the desire of Russia to gain direct access to the European civilisational core, which forced it to absorb and hold the limitrophes.

The collapse of the USSR and the socialist bloc, according to V. Tsymbursky, opened up a chance for Russia to get rid of this «complex of abducting Europe» and focus on the development and arrangement of its own civilisational platform. The concept of the «island of Russia» has a clear anti-imperial and isolationist character. An empire focused on keeping the limitrophes exhausts the Russian civilisational core, and the «abduction complex of Europe» forces Russia to participate in the affairs of a foreign (Western) civilisation, again, to the detriment of its own interests. That is why it is in Russia's interests to go beyond the Great Limitrophe (this is how V. Tsymbursky calls the entire set of intercivilisational «straits-territories» enveloping Russia from Eastern Europe to Central Asia), providing guarantees of its neutral status. The neutral Limitrophe, according to V. Tsymbursky, will play the role of a buffer between Russia and the West and ensure the minimum intersection of their mutual interests. Likewise, Russia should minimise its participation in globalisation processes under the auspices of the West.

Very originally V. Tsymbursky solves the problem of the demarcation of Russian and Western civilisations. Despite the Westernising pseudomorphosis of Russia, in his opinion, there is a set of external signs-classifiers, which makes it possible to quite clearly separate the cores of the Russian and European civilisations from each other. V. Tsymbursky, quite traditionally for Russian geopolitical thought, defines Europe as the Romano-Germanic world. In addition, the attributes of belonging to the West as a civilisation are Latin writing, traditional belonging to Western Christianity (Catholicism, Protestantism), as well as such signs as the prevalence of Gothic architecture. Russian civilisation, respectively, is characterised by the intersection of the signs of Slavic ethnicity, Cyrillic writing and traditional belonging to Orthodoxy. Accordingly, those regions of Eastern Europe where these signs are mixed in one way or another (for example, Slavic ethnicity in combination with Catholicism and Latin writing, Romanesque ethnicity in combination with Orthodoxy, etc.) are limitrophic.

Deeper civilisational differences are hidden behind these external cultural and geographical features. V. Tsymbursky metaphorically defines civilisation as «a special humanity on a special land». What unites people within the local civilisation into a «special humanity»? For this, the concept of a sacred vertical is introduced, which is understood as «religion or ideology that correlates the culture, social practice and geopolitics of a group of peoples with a transcendental higher reality» $[11$, p. 212]. In other words, the sacred vertical is an ideological construct that allows the civilisational community to realise itself as a special social subject and stand out among other human communities. As a rule, the sacred vertical contains ideas about a certain higher mission to which this civilisation is called. V. Tsymbursky does not reduce the sacred vertical to religion, as S. Huntington does, and notes that it can acquire both religious and secular (ideological) forms or be a mix of both. Moreover, the sacred vertical evolves along with civilisation and can undergo significant metamorphoses, up to a visible break with the previous tradition. As an example, we can cite the spiritual evolution of the West in modern times, when secular concepts based on the ideals of progress and the Enlightenment are replacing the religious worldview. Similarly, the victory of Bolshevism in Russia was also an indicator of the transformation of its sacred vertical.

It is with the development of the sacred vertical, which allows one or another territorially localised community to realise itself as a «special humanity on a special land», V. Tsymbursky connects the emergence of civilisation as such. He attributes the formation of the sacred vertical of Russia to the $16^{\text {th }}$ century and connects it with the doctrine «Moscow is the Third Rome». According to V. Tsymbursky, it was at this time that Muscovite Rus emerged from the shadow of Byzantium and finally acquired subjectivity as a «special humanity» with its own meanings of existence. So late, by historical standards, the formation of Russia's own sacred vertical in Russia allows V. Tsymbursky to define it as a young, retarded civilisation and explain by this its subsequent falling under the influence of Europe and the associated Westernising pseudomorphosis and the "complex of the abduction of Europe».

The concept of V. Tsymbursky shows the breakdown and fatigue from the «imperial burden» after the upheavals of the $20^{\text {th }}$ century and is an attempt to find 
a new place for Russia in the world outside the traditional paradigms. It seems that the unrealism of a number of its provisions was obvious already at the time of its creation, in particular, the very possibility of going into deep isolation and hiding from the global world behind a buffer-limitrophe. Nevertheless, it is an important step in the development of a civilisational approach. The main contribution of V. Tsymbursky can be considered the concept of the sacred vertical on a par with the development of the concept of «peoples between civilisations». The legacy of this author is still awaiting its comprehension.

\section{Библиографические ссылки}

1. Данилов АН. Новые геополитические реалии будущей цивилизации. Журнал Белорусского государственного университета. Социология. 2017;4:4-12.

2. Стёпин ВС. Цивилизация в эпоху перемен: поиск новых стратегий развития. Журнал Белорусского государственного университета. Социология. 2017;3:6-11.

3. Вульф Л. Изобретая Восточную Европу: карта цивилизации в сознании эпохи Просвещения. Федюкин И, переводчик. Москва: Новое литературное обозрение; 2003. 560 с.

4. Кагарлицкий БЮ. Периферийная империя: Россия и миросистема. Москва: Ленанд; 2018. 456 с.

5. Данилевский НЯ. Россия и Европа. Москва: Рипол Классик; 2017. 768 с.

6. Леонтьев КН. Византизм и славянство. Москва: Академический проект; 2017. 503 с. (Философские технологии).

7. Савицкий ПН. Евразийство [Интернет; процитировано 10 октября 2021 г.]. Доступно по: http://gumilevica.kulichki. net/SPN/spn09.htm.

8. Алексеев НН. Русский народ и государство. Москва: Аграф; 2003. 640 с. (Новая история).

9. Гумилев ЛН. Этногенез и биосфера Земли. [Интернет; процитировано 11 октября 2021 г.]. Доступно по: http://gumilevica.kulichki.net/EBE/.

10. Дугин АГ. Война континентов. Современный мир в геополитической системе координат. Москва: Академический проект; 2015. 359 с. (Gaudeamus).

11. Цымбурский ВЛ. Остров Россия. Геополитические и хронополитические работы. Москва: РОССПЭН; 2007. 544 с. (Политология России).

\section{References}

1. Danilov AN. New geopolitical realities of future civilization. Journal of the Belarusian State University. Sociology. 2017; 4:4-12. Russian.

2. Stepin VS. Civilization in the epoch of changes: search for new development strategies. Journal of the Belarusian State University. Sociology. 2017;3:6-11.

3. Wolff L. Inventing Eastern Europe: the map of civilization on the mind of the Enlightenment. Stanford: Stanford University Press; $1994.436 \mathrm{p}$.

Russian edition: Wolff L. Izobretaya Vostochnuyu Evropu: karta tsivilizatsii v soznanii epokhi Prosveshcheniya. Fedyukin I, translator. Moscow: Novoe literaturnoe obozrenie; 2003. 560 p.

4. Kagarlitskii BYu. Periferiinaya imperiya: Rossiya i mirosistema [Peripheral empire: Russia and the world system]. Moscow: Lenand; 2018. 456 p. Russian.

5. Danilevskii NYa. Rossiya i Evropa [Russia and Europe]. Moscow: Ripol Classic; 2017. 768 p. Russian.

6. Leont'ev KN. Vizantizm i slavyanstvo [Byzantism and Slavism]. Moscow: Akademicheskii proekt; 2017. 503 p. (Filosofskie tekhnologii). Russian.

7. Savitskii PN. Eurasianism [Internet; cited 2021 October 11]. Available from: http://gumilevica.kulichki.net/SPN/spn09. htm. Russian.

8. Alekseev NN. Russkii narod i gosudarstvo [Russian people and state]. Moscow: Agraf; 2003. 640 p. (Novaya istoriya). Russian.

9. Gumilev LN. Ethnogenesis and biosphere of the Earth [Internet; cited 2021 October 11]. Available from: http://gumilevica.kulichki.net/EBE/. Russian.

10. Dugin AG. Voina kontinentov. Sovremennyi mir v geopoliticheskoi sisteme koordinat [War of the continents. The modern world in the geopolitical coordinate system]. Moscow: Akademicheskii proekt; 2015. 359 p. (Gaudeamus). Russian.

11. Tsymburskii VL. Ostrov Rossiya. Geopoliticheskie i khronopoliticheskie raboty [Island Russia. Geopolitical and chronopolitical works]. Moscow: ROSSPEN; 2007. 544 p. (Politologiya Rossii). Russian. 